\title{
Dampak Pandemi Covid 19 terhadap Zakat Fitrah di Kota Pagar Alam
}

\author{
Imam Subhi, ${ }^{\bowtie}$ Risdianto, Zulki Firnanda, Renaldi Akbar \\ Sekolah Tinggi Ilmu Tarbiyah (STIT) Kota Pagar Alam, Sekolah Tinggi Ekonomi dan Bisnis Islam (STEBIS) \\ Kota Pagar Alam \\ elhafdatbi12@gmail.com, ${ }^{冈}$ risdianto1981@gmail.com, zulki0602@gmail.com, \\ Renaldyakbar17@gmail.com
}

\begin{abstract}
The covid 19 pandemic in Indonesia has been more than 1 year and 4 months epidemic and it is still going to worried rate as data released by the covid 19 task force stated that on July 17, 2021, the data was confirmed positive for 2,780,803, 2,204,491 people recovered and 71.397 people died. the number of pandemic is still going to grow in thousands. The impact of covid-19 is felt in all aspects of human life, one of which is with worship activities such as the implementation of zakat fitrah as regularly carried out every month of Ramadan. Pagar Alam town, based on this problem, the study used a descriptive qualitative approach, by taking samples of zakat management at the Nurul Huda mosque and the Raudlatul Jannah mosque. To obtain accurate and valid data, data collection techniques were used in the form of observation, interviews and documentation. The results stated that there was an impact caused by the Covid 19 pandemic, namely a decrease in number of muzakki (people who pay zakat) and mustahiq (people who receive zakat) in 2020, however, In 2021 will increase to stable. it happens in related to government policies such as applying new normal for Indonesian People.
\end{abstract}

\section{Keywords: Impact, Covid 19 and zakat fitrah}

\begin{abstract}
Abstrak
Wabah covid 19 di Indonesia sudah lebih dari 1 tahun 4 bulan mewabah dan masih akan mengkhawatirkan karena data yang dikeluarkan oleh gugus tugas covid 19 menyatakan bahwa pada 17 Juli 2021, data terkonfirmasi positif sebanyak 2.780.803, 2.204.491 orang sembuh dan 71.397 orang meninggal. jumlah pandemi masih akan bertambah dalam ribuan. Dampak covid-19 dirasakan di segala aspek kehidupan manusia, salah satunya dengan kegiatan ibadah seperti pelaksanaan zakat fitrah seperti yang rutin dilakukan setiap bulan Ramadhan. Kota Pagar Alam, berdasarkan permasalahan tersebut, penelitian ini menggunakan pendekatan kualitatif deskriptif, dengan mengambil sampel pengelolaan zakat di Masjid Nurul Huda dan Masjid Raudlatul Jannah. Untuk memperoleh data yang akurat dan valid digunakan teknik pengumpulan data berupa observasi, wawancara dan dokumentasi. Hasil penelitian menyebutkan bahwa terdapat dampak yang ditimbulkan dari adanya pandemi Covid 19 yaitu penurunan jumlah muzakki dan mustahiq pada tahun 2020, namun pada tahun 2021 akan meningkat menjadi stabil. hal itu terjadi terkait dengan kebijakan pemerintah seperti penerapan new normal bagi masyarakat Indonesia.
\end{abstract}

Kata kunci: Dampak, Covid 19 dan Zakat fitrah 


\section{Pendahuluan}

Pandemi covid 19 telah menjadi isu central seluruh negara di dunia yang kini sedang berusaha untuk menghentikan laju penyebarannya. Di Indonesia wabah ini telah lebih dari 1 tahun 4 bulan mewabah dan masih pada angka yang menghawatirkan sebagaimana data yang dilansir oleh satgas covid 19 menyatakan pada tanggal 17 Juli 2021 data terkonfirmasi positif 2.780.803, sembuh 2.204.491 orang dan yang meninggal 71.397 jiwa. ${ }^{1}$ Jumlah tersebut semakin bertambah hingga angka ribuan. Belum tuntas virus yang pertama, pada tahun 2020 ditemukan kembali virus jenis baru Sars Cov-2. Berbagai upaya dilakukan pemerintah untuk menekan jumlah wabah mulai kebijakan lock down, pembatasan sekala mikro, PPKM, kerjasama dengan berbagai negara dan yang sedang dilakukan ialah vaksinasi pada seluruh masyarakat dengan prioritasprioritas tertenu, untuk melakukan langkah strategis pencegahan laju wabah tersebut dan vaksinasi.

Dampak pandemi covid 19 hampir dirasakan diseluruh aspek kehidupan manusia, salah satunya bertepatan dengan moment lebaran sejak tahun 2020 dan 2021 tidak bisa dirayakan dengan sebagaimana biasanya, dan tahun ini pun pemerintah mengeluarkan kebijakan yang sama yang tertuan pada surat edaran menteri perhubungan SE. 42 Tahun 2021 Tentang petunjuk pelaksanaan perjalanan orang dalam negeri dengan transportasi perkeretaapian pada masa pendemi Corona Virus Disease 2019 (COVID19), dan nomor SE 43 Tahun 2021 Tentang petunjuk pelaksanaan perjalanan orang dalam negeri dengan transportasi darat pada masa pandemi Corona Virus Disease 2019 (Covid-19), melarang mudik ke kampung halaman sejak tanggal 6-17 Mei 2021 bagi seluruh masyarakat dan khusunya bagi ASN akan mendapatkan sanksi, langkah tersebut terpaksa dilakukan sebagai antisipasi munculny kluter baru di kampung halaman, dengan demikian volume pemudik berkurang drastis. ${ }^{2}$

${ }^{1}$ Covid19.go.id, "Peta Sebaran," accessed July 17, 2021, https://covid19.go.id/petasebaran.

2 "SE Menteri Perhubungan Nomor 49 Tahun 2021," 2021, https://covid19.go.id/p/regulasi/se-menteri-perhubungan-nomor-49-tahun-2021. 
Hal yang tak terduga ternyata kebijakan tersebut berpotensi berdampak pada hal lain yakni terkait dengan zakat fitrah yang dihimpun oleh amil zakat yang ada pada tiap masjid dan musholla, karena umumnya zakat fitrah dilakukan mendekati idul fitri sehingga bagi para perantau memiliki kesempatan untuk membayarkan zakatnya dikampung kelahiran, namun karena perantau banyak yang tidak mudik, maka terdapat potensi kemungkinan berdampak pada jumlah atau volume orang yang berzakat atau disebut muzakki, dan disisi lain berdampak juga pada melonjaknya jumlah fakir miskin karena dampak pemutusan hubungan kerja, atau bangkrutnya usaha yang dijalani.

Melihat fenomena itulah maka penelitian ini penting untuk dilakukan, dengan tujuan melihat secara detail terkait kemungkinan dampak yang ditimbulkan kebijakan pemerintah yang terkait dengan upaya pencegahan wabah covid 19, sekaligus diupayakan rekomendasi bagi fihak-fihak terkait untuk berkerjasama mencari solusi yang tepat dan cepat atas kondisi sedang terjadi.

\section{Metode Penelitian}

Penelitian dilakukan dengan pendekatan kualitatif deskriftif yang akan memberikan gambaran tentang foukus kajian yang diteliti, untuk mendapatkan data yang akurat dan valid maka dibutuhkan teknik pengumpulan data yang tepat, adapun teknik digunakan Pertama, observasi, dengan cara mencermati langsung proses penerimaan dan distribusi zakat fitrah yang dilakukan di masjid-masjid yang dijadikan objek penelitian. ${ }^{3}$ Kedua, dokumentasi terhadap data-data yang sudah ada diarsip-arsip panitia zakat fitrah yang dikodifikasi oleh pengurus masjid. ${ }^{4}$ Ketiga wawancara, teknik ini digunakan untuk mengkonfirmasi data-data amil zakat fitrah. Setelah data dari tiga teknik tersebut diperoleh maka dilakukan analisis data dengan metode triangulasi data, hal ini dilakukan untuk

\footnotetext{
${ }^{3}$ Imam Subhi and dkk, Metode Penelitian Kualitatif, Kuantitatif Dan PTK (Palembang: Noerfikri Offset, 2021).

${ }^{4}$ Iskandar, Metodologi Penelitian Pendidikan Dan Sosial: (Kuantitatif Dan Kualitatif), ed. H. Martinis Yamin (Jakarta: GP Press, 2008).
} 
memastikan bahwa data-data yang diperoleh dari berbagai sumber dan teknik terdapat keselarasan ataupun terjadi kontradiktif, dari data tersebut maka akan dilakukan penarikan kesimpulan. ${ }^{5}$

\section{Page|122 Hasil Penelitian}

Data yang diperoleh dari hasil obervasi ke lokasi pengumpulan zakat fitrah dari tahun 2019 s/d 2021 sebagai berikut:

Tabel 1.

Jumlah Muzakki dan Perolehan Zakat Fitrah 2019-2021

\begin{tabular}{|c|c|c|c|c|c|c|c|c|c|c|}
\hline \multirow{2}{*}{ NO } & \multirow{2}{*}{ NAMA MASJID } & \multicolumn{3}{|c|}{2019} & \multicolumn{3}{|c|}{2020} & \multicolumn{3}{|c|}{2021} \\
\hline & & $\mathbf{M z}$ & Bs & $\mathbf{R p}$ & $\mathbf{M z}$ & Bs & $\mathbf{R p}$ & $\mathbf{M z}$ & Bs & $\mathbf{R p}$ \\
\hline 1 & $\begin{array}{l}\text { Raudhatul } \\
\text { Jannah, Mekar } \\
\text { Alam Pagar Alam } \\
\text { Utara }\end{array}$ & 310 & 150 & 6.250 .000 & 250 & 100 & 3.750 .000 & 210 & 700 & 1.000 .000 \\
\hline 2 & $\begin{array}{l}\text { Nurul Huda, Desa } \\
\text { rempasai Kec. } \\
\text { Dempo Selatan }\end{array}$ & 423 & 757 & 3.000 .000 & 420 & 345 & 1.875 .000 & 765 & 1500 & 5.000 .000 \\
\hline
\end{tabular}

Catatan: Mz (jumlah muzakki), Bs (jumlah beras yang terkumpul dari seluruh muzakki), Rp (jumlah uang yang terkumpul dari seluruh muzakki)

Mencermati tabel di atas dipahami Pertama, dari aspek muzakki (orang yang berkewajiban menunaikan Zakat fitrah) di masjid Raudlotul Jannah selanjutnya disingkat (RJ) pada tahun 2019-2020 terjadi penurunan sebesar 60 orang (19\%), dan juga di tahun 2021 sebesar 40 orang atau 16\%, sementara masjid nurul huda selanjutnya disingkat $(\mathrm{NH})$ pada tahun 2019-2020 mengalami penurunan sedikit yaitu 3 orang atau 1\%, tapi ditahun 2021 mengalami kenaikan signifikan sebesar 345 orang 55\%. Dari data tersebut dapat disimpulkan bahwa jumlah Muzakki di masjid NH dan RJ pada tahun 2020 sama-sama mengalami penurunan, dan tahun 2021 di masjid NH terjadi kenaikan signifikan, tetapi di masjid RJ masih mengikuti tren penurunan sebagaimana tahun sebelumnya sekalipun jumlahnya lebih kecil.

\footnotetext{
${ }^{5}$ Sugiono, Metode Penelitian Kuantitatif, Kualitatif, Dan R\&D (Bandung: Alfabeta, 2010).
} 
Kedua, dari aspek beras yang diperolah oleh panitia zakat fitrah. Di masjid RJ pada tahun 2019-2020 terjadi penurunan perolehan beras sebesar $50 \mathrm{~kg}$ atau $33 \%$, dan pada tahun 2021 terjadi kenaikan signifikan sebesar $600 \mathrm{~kg}$ atau 6 kali lipat dari sebelumnya. Dimasjid NH tahun 2019-2020 terjadi penurunan sebesar $412 \mathrm{~kg}$ atau $54,4 \%$. Dari data tersebut menggambarkan secara jelas bahwa perolehan beras yang dikumpulkan oleh panitia zakat fitrah di dua masjid tersebut pada tahun 2020 mengalami penurunan, akan tetapi di tahun 2021 mengalami kenaikan signifikan pada dua masjid tersebut.

Ketiga, Dilihat dari perolan zakat berupa uang yang dikordinir oleh panitia zakat fitah di masjid RJ pada tahun 2019-2020 terjadi penurunan sebesar Rp.2.500.000 atau 40\%, penuruan juga dialami pada tahun 2021 sebesar Rp.2.750.000 atau 73 \%. Sementara di masjid NH pada tahun 2019-2020 mengalami penurunan Rp. 1.125 .000 atau 37.5\%, ditahun 2021 terjadi kenaikan Rp. 1.155 .000 atau $77 \%$.

Tabel 2.

Mustahiq dan jatah zakat fitrah 2019-2021

\begin{tabular}{|c|c|c|c|c|c|c|c|c|c|c|}
\hline \multirow{2}{*}{ NO } & \multirow{2}{*}{ NAMA MASJID } & \multicolumn{3}{|c|}{2019} & \multicolumn{3}{|c|}{2020} & \multicolumn{3}{|c|}{2021} \\
\hline & & Ms & $\mathbf{K g}$ & Rp & Ms & $\mathbf{K g}$ & Rp & Ms & $\mathbf{K g}$ & $\mathbf{R p}$ \\
\hline \multirow[t]{4}{*}{1} & Raudhatul & 25 & 6 & 270.000 & 20 & 4 & 187.500 & 200 & 3 & 50.000 \\
\hline & Jannah, Mekar & & & & & & & & & \\
\hline & Alam Pagar Alam & & & & & & & & & \\
\hline & Utara & & & & & & & & & \\
\hline \multirow[t]{3}{*}{2} & Nurul Huda, Desa & 95 & 8 & 50.000 & 90 & 9 & 50.000 & 115 & 10 & - \\
\hline & rempasai Kec. & & & & & & & & & \\
\hline & Dempo Selatan & & & & & & & & & \\
\hline
\end{tabular}

Catatan: Ms (jumlah mustahiq), Bs (jumlah beras yang diperoleh tiap mustahiq), Rp (jumlah uang yang diperolah tiap mustahiq)

Mencermati tabel dapat disimpulkan dari tiga aspek, Pertama aspek mustahiq atau orang yang berhak mendapatkan jatah zakat fitrah di masjid RJ tahun 2019-2020 mengalami pengurangan sebanyak 5 orang atau 20\%, ditahun 2021 terjadi kenaikan signifikan sebanyak 180 orang atau 90\%. Sementara dimasjid NH tahun 2019-2021 terjadi penurunan jumlah mustahiq sebanyak 5 orang atau $5 \%$, dan ditahun mengalami pertambahan yang signifikan sebanyak 25 orang atau $21 \%$. Kedua dari sisi jatah beras yang diberikan panitia tiap 
mustahiq di masjid RJ tahun 2019-2020 mengalami penurunan sebesar $2 \mathrm{~kg}$ atau 33\%, ditahun 2021 juga terjadi penuruan jatah kembali sebesar $1 \mathrm{~kg}$ atau 25\%. Adapun dimasjid $\mathrm{NH}$ tahun 2020 mengalami kenaikan $1 \mathrm{~kg}$ atau $11 \%$ dan ditahun 2021 juga terjadi kenaikan dengan jumlah yang sama $1 \mathrm{~kg}$ atau $10 \%$. Ketiga dari sisi jumlah uang yang diterima masing-masing mustahiq, di masjid RJ tahun 2020 terjadi penurunan jumlah jatah per mustahiq sebesar Rp. 82.500 atau 30,5 \%, di tahun 2021 mengalami penurunan lebih signifikan sebesar Rp.137.500. atau 73 \%. Di masjid NH tahun 2020 terjadi stabil yakni tetap diangka Rp.50.000 dan pada tahun 2021 tidak zakat berupa uang, hanya beras yang dibagikan oleh amil zakat fitrah.

\section{Pembahasan}

Dari ulasan tabel 1 jumlah muzakki dan perolehannya diatas yang dihimpun dari dua masjid dapat disimpulkan bahwa pada tahun 2020 semua aspek mengalami penuruan jumlah, sementara di tahun 2021 terjadi penurunan di beberapa asepk saja, bahkan di masjid NH justru mengalami keniakan signifikan. Demikian juga pada tabel 2, mustahiq dan jatah zakat fitrah, dari gambaran data tersebut dapat ambil benang merah bahwa pada tahun 2020 panitia zakat fitrah mendapat data mengalami penurunan baik dari sisi jumlah mustahiq, jumlah beras dan juga jumlah uang yang diterima, sementara pada tahun 2021 justru mengalmi kenaikan yang signifikan dari 25-180 orang mustahiq, hal ini berdampak dengan jumlah beras yang diterima oleh mustahiq juga mengalami penurunan, langkah tersebut sebagai antisipasi supaya seluruh mustahiq mendapat jatah secara adil.

Masa pandemi covid 19 di indonesia pertama kali diumumkan pada tanggal 2 Maret 2020 yang ditemukan pada dua warga Depok, Jawa Barat. Data hingga Sabtu, 28 Maret 2020 jumlah warga yang dinyatakan positif terkena virus corona mencapai 1.155 dan 102 di antaranya meninggal dunia. Cepatnya penyebaran virus ini di Indonesia menurut Juru Bicara pemerintah untuk penanganan COVID-19. ${ }^{6}$

\footnotetext{
${ }^{6}$ Niken Widya Yunita, "Penyebab, Asal Mula, Dan Pencegahan Virus Corona Di Indonesia," Detik News, 2020, https://news.detik.com/berita/d-4956764/penyebab-asal-mula-danpencegahan-virus-corona-di-indonesia.
} 
Ukuran virus ini partikel 60-140 nm, Dalam penjabaran lebih rinci bahwa virus yang merupakan virus RNA strain tunggal positif ini yang menginfeksi saluran pernafasan. Penegakan diagnosis dimulai dari gejala umum seperti demam, batuk, sulit bernafas hingga adanya kontak erat dengan negara-negara yang sudah terinfeksi. Pengambilan swab tenggorokan dan daluran nafas menjadi dasar penegakan diagonosis coronavirus dieases. ${ }^{8}$

Mengingat ada derasnya penyebaran virus tersebut maka pemerintah mengambil beberapa kebijakan diantaranya pemerintah menerbitkan beberapa kebijakan diantaranya:

1. Peraturan Pemerintah Nomor 21 tahun 2020 tentang Pembatasan Sosial Berskala Besar dalam rangka Percepatan Penanganan Corona Virus Disease 2019 (Covid-19) ditetapkan pada 31 Maret 2020. Pemerintah Daerah (Pemda) dapat melakukan Pembatasan Sosial Berskala Besar (PSBB) untuk satu provinsi atau kabupaten/kota tertentu. PSBB dilakukan dengan pengusulan oleh gubernur/bupati/walikota kepada Menteri Kesehatan.

2. Peraturan Menteri Kesehatan No. 9 Tahun 2020 tentang Pedoman PSBB dalam rangka Percepatan Penanganan Covid-19 ditetapkan pada 3 April 2020. Kebijakan PSBB antara lain: 1) Peliburan sekolah dan tempat kerja; 2) Pembatasan kegiatan keagamaan; 3) Pembatasan kegiatan di tempat/fasilitas umum; 4) Pembatasan kegiatan sosial budaya; 5) Pembatasan moda transportasi; dan 6) Pembatasan kegiatan lainnya terkait aspek pertahanan dan keamanan.

3. Pada 7 April 2020, Menkes menyetujui PSBB untuk diterapkan di DKI Jakarta. PSBB dilakukan selama 14 hari. Ojek online dilarang membawa penumpang. Jadwal KRL dievaluasi ulang dan dikurangi. ${ }^{9}$

${ }^{7}$ Meng and Dkk, "CT Imaging and Clinical Course of Asymptomatic Cases with Covid-19 Pneumonia at Admission in Wuhan," Journal of Infection, 2020, 33-39, https://doi.org/doi.org/10.1016/j.jinf.202 0.04.004.

${ }^{8}$ Yuliana, "Corona Virus Dieases (Covid 19) Sebuah Tinjaun Literatur," Wellness Dan Healty Magazine 2, no. 1 (2020): 192.

\footnotetext{
${ }^{9}$ Kementerian Luar Negeri Republik Indonesia, "Kebijakan Pemerintah Republik Indonesia Terkait Wabah Covid," Kedutaan Besar RI di Brussel Belgia, 2020,
} 
Tidak hanya itu menjelang bulan ramadhan dan idul fitripun pemernitah mengeluarkan kebijkan sebagaimana disampaikan oleh Direktur Jenderal Bimas Islam Kemenag Prof. Dr. Phill. H. Kamarudin Amin, M. A. menyampaikan bahwa Kementerian Agama telah mengeluarkan 2 (dua) Surat Edaran kaitannya dengan pelaksanaan bulan Ramadhan tahun 2020. "Yaitu Surat Edaran Nomor 6 tentang panduan ibadah di bulan Ramadhan dan Idul Fitri 1 Syawal 1441 H serta Surat Edaran Nomor 8 tentang pembayaran dan pendistribusian zakat. Selain itu juga ada Surat Edaran dari Dirjen Bimas Islam," Kamarudin menjelaskan bahwa surat edaran yang dikeluarkan tentu saja menguatkan kebijakan nasional dalam rangka Pembatasan Sosial Beskala Besar (PSBB). "Inti dari surat edaran tersebut adalah menguatkan kebijakan nasional tentang PSBB agar semua amaliyah di bulan Ramadhan agar dikerjakan di rumah. Seperti himbauan shalat tarawih agar dilaksanakan di rumah, buka puasa bersama tidak perlu dilaksanakan, tilawah dan tadarus dilaksanakan di rumah saja, dengan semangat tidak akan ada perkumpulan-perkumpulan. ${ }^{10}$

Dengan diberlakukannya kebijakan tersebut maka masyarakat Islam meniadakan tradisi dibulan ramadhan dan menjelang idul fitri yakni mudik lebaran, sehingga kampung-kampung yang biasanya ramai didatangi para perantau, pada tahun itu terlihat sepi, tidak seramai tahun 2019, selain itu pandemi tersebut juga berdampak pada sektor ekonomi atau pendapat masyarakat kota pagar alam khusunya bagi para pelaku usaha kecil dan menengah yang sangat terdampak hingga ada yang gulung tikar, bahkan ada warga pagar alam yang pulang kampung dikarenakan terkena PHK (pemutusan hubungan kerja), data ini diperkuat oleh statatemen Kementerian Ketenagakerjaan (Kemnaker) menyebut ada 29,4 juta orang terdampak pandemi Covid-19 yaitu Pemutusan Hubungan Kerja (PHK), dirumahkan tanpa upah hingga pengurangan jam kerja dan upah. ${ }^{11}$ Situasi tersebut berdampak juga

https://kemlu.go.id/brussels/id/news/6349/kebijakan-pemerintah-republik-indonesia-terkaitwabah-covid.

${ }^{10}$ Kabar Latuharhari, "Pelaksanaan Ibadah Ramadhan Di Tengah Pandemi Covid-19," Komnasham RI, 2020, https://www.komnasham.go.id/index.php/news/2020/4/24/1368/ pelaksanaan-ibadah-ramadhan-di-tengah-pandemi-covid-19.html.

${ }^{11}$ Agustina Triatmojo, "Kemnaker: 29,4 Juta Pekerja Terdampak Pandemi Covid-19, DiPHK Hingga Dirumahkan," Tribun News Com, 2021, 
terhadap pada zakat fitrah yang dikelola oleh dua masjid tersebut hal ini terbukti dengan adanya penurunan di seluruh aspek yang diamati seperti muzakki, perolehan beras, perolehan uang, jumlah mustahiq, dan jatah zakat fitrah baik berupa beras maupun berupa uang.

Page | 127

Setelah dua bulan kebijakan PSBB di beberapa wilayah di Indonesia, Pemerintah mulai melakukan kebijakan new normal. Menurut Ketua Tim Pakar Gugus Tugas Percepatan Penanganan Covid-19 Wiku Adisasmita, new normal adalah perubahan perilaku untuk tetap menjalankan aktivitas normal namun dengan ditambah menerapkan protokol kesehatan guna mencegah terjadinya penularan Covid-19. Segala aktivitas baik ekonomi, ibadah, maupun sosial mulai mempersiapkan menuju keadaan new normal agar tetap produktif. Presiden Jokowi pada saat berkunjung ke Kantor Gugus Tugas Penanganan Covid-19 di Graha Badan Nasional Penanggulangan Bencana (BNPB), menyampaikan lima arahan terkait adapatasi kebiasaan baru agar masyarakat tetap produktif dan aman dari penularan Covid-19, yaitu (1) melakukan sosialisasi yang massif terkait protokol kesehatan yang harus diikuti; (2) melakukan perhitungan yang cermat dalam mengambil kebijakan yang harus didasarkan pada data dan fakta di lapangan; (3) menentukan prioritas yang disiapkan secara matang mengenai sektor dan aktivitas yang bisa dimulai dan dibuka secara bertahap; (4) memperkuat konsolidasi; dan (5) koordinasi Pemerintah Pusat dengan Pemerintah Daerah serta melakukan evaluasi secara rutin. Melalui Keputusan Menteri Kesehatan Nomor HK.01.07/MENKES/328/2020 Tentang Panduan Pencegahan dan Pengendalian Corona Virus Disease 2019 (Covid-19) di Tempat Kerja Perkantoran Dan Industri Dalam Mendukung Keberlangsungan Usaha Pada Situasi Pandemi, Pemerintah memberikan panduan pencegahan dan pengendalian Covid-19 di tempat kerja. Hal ini diharapkan dapat meminimalisir risiko dan dampak Covid-19 di tempat kerja khususnya di area perkantoran dan industri dimana banyak orang berkumpul dalam satu tempat. ${ }^{12}$

https://www.tribunnews.com/bisnis/2021/03/27/kemnaker-294-juta-pekerja-terdampak-pandemicovid-19-di-phk-hingga-dirumahkan.

12 KPKNL Palangkaraya, "Beradaptasi Dengan Tatanan Normal Baru (New Normal)," Kementerian Keuangan RI, 2020, https://www.djkn.kemenkeu.go.id/kpknl-palangkaraya/bacaartikel/13208/Beradaptasi-dengan-Tatanan-Normal-Baru-New-Normal.html. 
Kebijakan tersebut juga berlaku hingga tahun 2021, oleh karena itu mengingat masyarakat juga sudah mulai terbiasa dengan situasi tersebut, aktifitas ibadah, ekonomi dan kegiatan kemasyarakatan Pagar Alam juga kembali terlihat pulih kembali sekalipun ini tidak bisa dibandingkan dengan sebelum masa pandemi covid 19 terjadi. Oleh karena itu situasi tersebut juga berpengaruh kepada pengelolaan zakat fitrah yang dikelola di dua masjid tersebut, sehingga dibeberapa aspek mengalami kenaikan baik dari sisi muzakki dan ternyata itu diikuti dengan adanya kenaikan jumlah mustahiq.

\section{Simpulan}

Mencermati kondisi tersebut dapat dikatakan bahwa pandemi covid 19 mememiliki pengaruh yang signifikan terhadap pengeolaan zakat fitrah di dua masjid di pagar alam terutama dilihat pada tahun 2020. Pada tahun 2021 terjadi kenaikan dari sisi muzakki tapi juga diikuti dengan kenaikan mustahiq. Padahal situasi yang ideal adalah kenaikan jumlah muzakki semestinya diikuti dengan penurunan jumlah mustahiq, dengan dasar bahwa orang-orang yang dulunya berstatus menjadi mustahiq tergerak untuk berganti status menjadi muzakki. 


\section{DAFTAR PUSTAKA}

Covid19.go.id. "Peta Sebaran." Accessed July 17, 2021. https://covid19.go.id/petasebaran.

Iskandar. Metodologi Penelitian Pendidikan Dan Sosial: (Kuantitatif Dan Kualitatif). Edited by H. Martinis Yamin. Jakarta: GP Press, 2008.

Kabar Latuharhari. "Pelaksanaan Ibadah Ramadhan Di Tengah Pandemi Covid19." Komnasham RI, 2020.https://www.komnasham.go.id/index.php/news /2020/4/24/1368/pelaksanaan-ibadah-ramadhan-di-tengah-pandemi-covid -19.html.

Kementerian Luar Negeri Republik Indonesia. "Kebijakan Pemerintah Republik Indonesia Terkait Wabah Covid." Kedutaan Besar RI di Brussel Belgia, 2020. https://kemlu.go.id/brussels/id/news/6349/kebijakan-pemerintah-republikindonesia-terkait-wabah-covid.

KPKNL Palangkaraya. "Beradaptasi Dengan Tatanan Normal Baru (New Normal)." Kementerian Keuangan RI, 2020. https://www.djkn.kemenkeu.go.id/kpknlpalangkaraya/baca-artikel/13208/Beradaptasi-dengan-Tatanan-NormalBaru-New-Normal.html.

Meng, and Dkk. "CT Imaging and Clinical Course of Asymptomatic Cases with Covid-19 Pneumonia at Admission in Wuhan." Journal of Infection, 2020, 3339. https://doi.org/doi.org/10.1016/j.jinf.202 0.04.004.

Niken Widya Yunita. "Penyebab, Asal Mula, Dan Pencegahan Virus Corona Di Indonesia." Detik News, $2020 . \quad$ https://news.detik.com/berita/d4956764/penyebab-asal-mula-dan-pencegahan-virus-corona-di-indonesia.

"SE Menteri Perhubungan Nomor 49 Tahun 2021," 2021. https://covid19.go.id/p/regulasi/se-menteri-perhubungan-nomor-49-tahun2021.

Subhi, Imam, and dkk. Metode Penelitian Kualitatif, Kuantitatif Dan PTK. Palembang: Noerfikri Offset, 2021. 
Imam Subhi, Risdianto, Zulki Firnanda, Renaldi Akbar

Sugiono. Metode Penelitian Kuantitatif, Kualitatif, Dan R\&D. Bandung: Alfabeta, 2010.

Triatmojo, Agustina. "Kemnaker: 29,4 Juta Pekerja Terdampak Pandemi Covid-19, Page|130 Di-PHK Hingga Dirumahkan." Tribun News Com. 2021. https://www.tribunnews.com/bisnis/2021/03/27/kemnaker-294-jutapekerja-terdampak-pandemi-covid-19-di-phk-hingga-dirumahkan.

Yuliana. "Corona Virus Dieases (Covid 19) Sebuah Tinjaun Literatur." Wellness Dan Healty Magazine 2, no. 1 (2020): 192. 